\title{
The Basic Cardiovascular Responses to Postural Changes, Exercise, and Cold Pressor Test: Do They Vary in Accordance with the Dual Constitutional Types of Ayurveda?
}

\author{
Piyush Kumar Tripathi, ${ }^{1}$ Kishor Patwardhan, ${ }^{1}$ and Girish Singh ${ }^{2}$ \\ ${ }^{1}$ Department of Kriya Sharir, Faculty of Ayurveda, Institute of Medical Sciences, Banaras Hindu University, Varanasi, \\ Uttar Pradesh, 221005, India \\ ${ }^{2}$ Division of Biostatistics, Department of Community Medicine, Institute of Medical Sciences, Banaras Hindu University, Varanasi, \\ Uttar Pradesh, 221005, India
}

Correspondence should be addressed to Kishor Patwardhan, patwardhan.kishor@gmail.com

Received 16 April 2010; Accepted 30 June 2010

Copyright (๑) 2011 Piyush Kumar Tripathi et al. This is an open access article distributed under the Creative Commons Attribution License, which permits unrestricted use, distribution, and reproduction in any medium, provided the original work is properly cited.

According to Ayurveda, the native Indian system of healthcare, three Doshas, namely, Vata, Pitta, and Kapha, are the basic mutually reciprocal mechanisms that are responsible for the maintenance of homeostasis in human beings. Ayurveda classifies entire human population into seven constitutional types (Prakriti), based on the dominance of any single or a combination of two or three Doshas. Considering the fact that, in the recent past there have been several studies that have proposed some important genetic, biochemical and haematological bases for Prakriti, we conducted the present study in 90 randomly selected clinically healthy volunteers belonging to dual constitutional types (Dvandvaja Prakriti) to evaluate the variability of heart rate and arterial blood pressure in response to specific postural changes, exercise, and cold pressor test. The results of this study, in general, suggest that these basic cardiovascular responses do not vary significantly as per the dual constitutional types. However, we noted a significant fall in the diastolic blood pressure immediately after performing the isotonic exercise for five minutes, in Vata-Kapha individuals in comparison to the other two groups, namely, Pitta-Kapha and Vata-Pitta.

\section{Introduction}

According to Ayurveda, the native Indian system of medicine, the entire human population can be divided into seven constitutional types (Prakriti) [1-3]. As per this system, three mutually reciprocal mechanisms known as Doshas, namely, Vata, Pitta, and Kapha are responsible for the maintenance of homeostasis, and thus, the health [4]. Therefore, the constitutional types identified in Ayurveda are also based on the physiological dominance of any single or a combination of two or three Doshas in an individual [5]. Several mutually opposite attributes have been ascribed to these Doshas (Table 1), and each of these attributes produces a specific observable trait/feature/character (phenotype) in the individual. One's constitutional type is determined on the basis of these physical, physiological, and psychological features and this constitution, in turn, determines the predisposition to diseases, management, and the life-style regimen suitable for an individual [3]. The scheme of dividing the population into specific constitutional types is not unique to Ayurveda and is prevalent in other traditional systems of healthcare like Traditional Chinese Medicine, Kampo (the traditional medicine of Japan) and Sasang Constitutional Medicine of Korea as well [6-9]. The Hippocrates' model of four humours, the classification of human personality types by Kretschmer \& Sheldon and the description of introversion-extroversion and neuroticism by Eysenck are all based on similar conceptual framework [1013].

As per the explanations found in Ayurveda textbooks, the salient observable features among the individuals belonging to Vata constitution include: a weakly developed body build, irregular appetite, irregular food and bowel habits, rapid physical activities, dry skin and hair, and intolerance 
TABLE 1: The different attributes of three Doshas responsible for rendering them mutually reciprocal.

\begin{tabular}{|c|c|c|}
\hline Vata & Pitta & Kapha \\
\hline Nonunctuous/dry (Ruksha) & - & Unctuous (Snigdha) \\
\hline Light (Laghu) & - & Heavy (Guru) \\
\hline Cold (Shita) & Hot (Ushna) & Cold (Shita) \\
\hline- & Pungent and sour (Amla and Katu) & Sweet (Madhura) \\
\hline - & Liquid (Drava) & Solid (Sandra) \\
\hline- & Sharp (Tikshna) & Dull (Manda) \\
\hline Coarse/rough (Parusha) & - & Smooth (Shlakshna) \\
\hline Nonslimy (Vishada) & - & Slimy (Vijjala) \\
\hline Mobile (Chala) & - & Rigid (Stimita) \\
\hline Abundant (Bahu) & - & - \\
\hline Swift (Shighra) & - & - \\
\hline- & Fleshy smell (Visra) & - \\
\hline- & - & Essence (Saara) \\
\hline- & - & Clear (Accha) \\
\hline - & - & Soft (Mridu) \\
\hline
\end{tabular}

for cold temperature. The individuals belonging to Pitta Prakriti are characterised by the features like: high frequency and intensity of appetite and thirst, high tendency for perspiration, easy irritability, and good tolerance for cold temperature. On similar lines, Kapha Prakriti individuals are characterised by low appetite and digestion, less mobility, good memory, good resistance against diseases, and cool temperament [3].

In the recent past, there have been several interesting studies indicating either a genetic or a biochemical basis for these constitutional types described in Ayurveda. Udupa $\mathrm{KN}$ and others determined the basal blood levels of three neurotransmitters, namely, Acetylcholine, Catecholamines and Histamine along with the concerning enzymes like Cholinesterase, Monoamine oxidase and Histaminase and reported that the normal persons with features of Vata, Pitta and Kapha constitutions exhibited a relative preponderance of blood Cholinesterase, Monoamine oxidase and Histaminase activity, respectively [14]. Patwardhan B and others hypothesized that there could be a genetic basis for the three major constitutions described in Ayurveda. They evaluated 76 subjects both for their Prakriti and human leukocyte antigen (HLA) DRB1 types and observed a reasonable correlation between HLA type and Prakriti type [15, 16]. Prasher B and others observed that individuals from the three most contrasting constitutional types exhibited striking differences with respect to biochemical and hematological parameters and at genome wide expression levels. They also reported that biochemical profiles like liver function tests and lipid profiles and hematological parameters like hemoglobin levels exhibited differences between Prakriti types. Thus, they concluded that Ayurveda-based method of phenotypic classification of extreme constitutional types may be utilized to uncover genes that may contribute to systemlevel differences in normal individuals [3]. Ghodke Y and others carried out CYP2C19 genotyping in 132 unrelated healthy subjects of either gender, and, observed significant association between CYP2C19 genotype and major classes of Prakriti types. They reported that the extensive metabolizer genotype was found to be predominant in Pitta Prakriti, and the poor metabolizer genotype was highest in Kapha Prakriti when compared with other two Prakriti groups [17].

In spite of these reports, there are quite a few difficulties that have been encountered in assessing one's Ayurveda constitution. The accurate determination of one's constitution has been a problem in other traditional systems of medicine as well [18]. The age, physical and psychological status of the individual along with the season prevailing while assessing one's constitution are the major factors that tend to distort the outcome of this exercise. Differences in the subjective perceptions of the physicians also can make the assessment ambiguous. The absence of definite criteria for designating one's constitution to be either due to a single Dosha or due to two or three Doshas is another problem. Also, there is no data available to show the predominance of a particular type of Prakriti in a particular population. Nonavailability of the standardised and validated questionnaires to assess Prakriti makes the situation even more difficult. Most of the questionnaires available today are either based on too many textbooks or require physicianparticipant interaction in the form of a personal interview or even sometimes a detailed physical examination. This situation has resulted into the problems like: too lengthy questionnaires, inclusion of contradictory statements from different textbooks, and unnecessary divulgence of personal details of the participants.

In the present study, we administered a modified version of the "Self-assessment questionnaire" [19] prepared originally by Patwardhan K and Sharma R to 150 randomly chosen healthy volunteers and shortlisted 90 volunteers who fulfilled the criteria to be designated as belonging to a dual 
type of constitution (Dvandvaja Prakriti). We investigated for a possible correlation between these dual constitutional types and certain basic cardiovascular responses to postural changes, isotonic exercise (involving the shortening of muscles with the tone remaining constant), isometric exercise (involving the contraction of muscles without shortening), and cold pressor test.

\section{Objectives of the Study}

Almost all the studies on Prakriti published so far have concentrated mainly on the individuals belonging to three extreme constitutional types, that is, Vata, Pitta and Kapha [3, 14-17]. In fact, as per our experience, the chances of encountering an individual with a truly extreme constitutional type are very rare. Though at variable degrees, one or the other secondary Dosha usually expresses its corresponding features in most of the individuals along with the primary Dosha. Therefore, we decided to design a study, where, only those individuals belonging to a dual constitutional type would be included. Further and more, no study available has so far concentrated on simple and clinically useful noninvasive parameters like heart rate (HR) and arterial blood pressure (ABP) variability in response to posture, exercise and cold pressor test. We hypothesised that these parameters, if showed some variability in accordance with the constitutional types, would serve as good indicators to determine and verify one's Prakriti along with offering some help in determining ones' predisposition to diseases. When parameters like blood levels of catecholamines show variability in accordance to Prakriti, it was logical to assume that some other basic clinical parameters might as well show similar variability.

With these objectives we planned the present study, where, 90 randomly selected clinically healthy volunteers belonging to the dual constitutional types were studied for the variability of $\mathrm{HR}$ and $\mathrm{ABP}$ in response to posture, exercise and cold pressor test.

\section{Material and Methods}

3.1. Population. Population for the present study was defined in terms of the students of either gender aged between 18-35 years and registered during the years 2008 and 2009 under the Bachelor of Ayurveda Medicine and Surgery (BAMS) and Ayurveda Vachaspati -MD(Ay)/ Ayurveda DhanvantariMS(Ay) programmes in the Faculty of Ayurveda, Institute of medical Sciences, Banaras Hindu University.

3.2. Randomization and Sampling Procedure. A list of students registered under BAMS and $\mathrm{MD}(\mathrm{Ay}) / \mathrm{MS}($ Ay) courses was prepared, and all the names were entered in a column in the Microsoft Excel 2007 workbook. Then, the formula $=\mathrm{RAND}()$ was entered into the first cell of an empty column next to the column that was to be randomized. The RAND() function inserts a random number between zero and one into the cell. The whole column was then pasted with the RAND() function, and thus, a column of random numbers was generated. The entire sheet was then selected, and the data was sorted by the column containing the random numbers. Now, the complete list of the students stood randomized. The first 150 students from this list were administered with the self-assessment questionnaire to assess Prakriti after obtaining their written consent to participate in the study. This population included those freshly registered students who had no idea regarding the Prakriti $(n=55)$ and also those who had studied Prakriti thoroughly in their course of studies $(n=95)$. The clearance was obtained from the ethical committee of the University before the study was started.

\subsection{Assessment of Prakriti among the Volunteers}

3.3.1. Preparation of the Questionnaire. We modified the "Self-assessment questionnaire for determining Prakriti" originally designed by Patwardhan and Sharma [19] and used it for the assessment of Prakriti of the individuals in the present study. This questionnaire is designed on the basis of the explanation found in Charaka Samhita, one of the most authentic textbooks on Ayurveda, authored around 1000 years BC [20]. This explanation is, in turn, based on the specific attribute (Guna) of a particular Dosha [5]. Charaka Samhita explains the specific attributes of a particular Dosha along with the description of the specific features these attributes produce in an individual. Thus, Vata, Pitta, and Kapha have been assigned with eight, five and twelve attributes (Guna), respectively. Furthermore, each attribute produces one or more observable features at the physical, physiological, or psychological domains.

Thus, three Doshas are neither assigned with equal number of attributes nor do they produce equal number of observable features in a given individual. This situation compelled us to adopt the self-assessment questionnaire which expresses the dominance of each Dosha in terms of percentage scores, and thus, makes the comparison of Dosha dominance quantitatively possible.

This questionnaire is designed in such a way that, each feature as described in Charaka Samhita (Vimana Sthana) has been converted into a simple question/statement. The respondents were required to record their agreement or disagreement with the statement/question in a column provided for the purpose in the form of "yes" or "no." The scores to be allotted for a particular type of response were specified against the statement in a separate column. It was clearly mentioned that if the response of the individual was not the one mentioned in the column, the score to be allotted was zero.

We modified the said questionnaire to suit the needs of our study (see data-1 in Supplementary Material available online at doi: 10.1155/2011/251850). For the sake of convenience in the calculations, we allotted a total of 120 scores for each Guna. If a particular Guna produced a single feature, a full of 120 scores were allotted to that feature, when found in the individual. On the other hand, if a Guna produced more than one feature, 120 scores were divided equally into the specific number of features that the particular Guna produced. For example, if a particular Guna produced four 
features, 120 scores were divided by four, resulting in 30 scores for each feature. This new scoring pattern avoided the need of scores being allotted in fractional numbers. We also modified certain questions/statements to suit the mindset of the student population. Thus, the final maximal scores according to this questionnaire were 960 for Vata, 600 for Pitta, and 1440 for Kapha. The percentage dominance of a Dosha in an individual was calculated on the basis of the total scores obtained for each Dosha by simple mathematical calculation as shown in:

Total scores scored by an individual for a Dosha $\times 100$

Total scores allotted to that Dosha

At the end of this exercise, the respondents could calculate the scores for different Doshas by themselves and could understand the Dosha dominance in terms of percentage scores. As the questionnaire was of "Self-assessment" type, the respondents were not asked to submit their completed questionnaires; instead, they were asked to record and submit the Dosha predominance in the form of percentage scores. The advantage of doing so was that the respondents could answer all the questions honestly without having to face any questions from the interviewer. Also, this helped them to overcome any apprehension related to unnecessary divulgence of their personal details.

3.3.2. Validation of the Questionnaire. To verify the results of this newly designed questionnaire, the questionnaire was correlated with another questionnaire that was already in use in the department of Kriya Sharir. The questionnaire that was already in use, required the physician-participant interaction and incorporated all the views expressed in different textbooks of Ayurveda. As this questionnaire too, gave the results in terms of percentage dominance of Doshas, we decided to administer both the questionnaires to 50 volunteers randomly. After this, the percentage scores recorded for Vata, Pitta, and Kapha were correlated using the software Statistical Package for Social Sciences (SPSS version 11.5), and the Pearson's Correlation Coefficient $(r)$ was determined. At the end of this exercise, in all the three cases of Vata, Pitta and Kapha, we noted a positive correlation, and this correlation was significant as far as the measurement of Vata $(r=0.305, P=.015)$ and Kapha $(r=0.341, P=.031)$ was concerned. However, the correlation was not significant for Pitta, though the Pearson's Correlation Coefficient was positive ( $r=0.237, P=.097)$.

Validation of this kind of questionnaires remains to be a major problem in complementary and alternative medicine (CAM)- related research studies. The question as to whether the original questionnaire (with which the newly developed questionnaire was compared) was really accurate-remains unanswered in most of the cases. This is mostly because all such questionnaires try to measure some subjective parameters, and therefore, it is quite possible that the newly developed questionnaire is more sensitive than the original one, and yet, the correlation may still remain weak. Moreover, a correlation coefficient of 0.30 is usually taken as medium effect size in power analysis and sample size determination $[21,22]$. On these considerations, we treated the newly designed questionnaire to be validated.

\subsubsection{Procedure Adopted to Assign the Dual Constitutional} Type (Dvandvaja Prakriti) Status. The maximal (primary), moderate (secondary), and minimal (tertiary) Doshas were noted in terms of percentage scores and the following conditions were applied for designating an individual to be belonging to Dvandvaja Prakriti.

(a) The scores for the secondary Dosha should be at least $50 \%$ of the primary Dosha.

(b) The difference between the tertiary Dosha and the secondary Dosha should be at least $25 \%$ of the secondary Dosha.

Out of 150 volunteers, 90 individuals fulfilled both the above criteria and the Prakriti of these volunteers was designated as Vata-Pitta, Pitta-Kapha, or Vata-Kapha. While designating the Prakriti, the individuals with Vata as the primary Dosha and Pitta as the secondary Dosha (i.e., Vata-Pitta individuals, $n=4$ ) and the individuals with Pitta as the primary Dosha and Vata as the secondary Dosha (i.e., Pitta-Vata individuals, $n=15$ ) were considered to be equivalent and were grouped under Vata-Pitta. Similarly, the Pitta-Kapha individuals $(n=21)$ and the Kapha-Pitta individuals $(n=29)$ were treated to be equivalent and were grouped under Pitta-Kapha. On similar lines, the VataKapha individuals $(n=5)$ and the Kapha-Vata individuals $(n=16)$ were treated to be equivalent and were grouped under Vata-Kapha. This was done to avoid the necessity of creating six groups of dual Prakriti, which would have been a deviation from the Ayurveda textbooks.

These volunteers were enrolled in the study only after undergoing the clinical examination and being declared clinically healthy and physically fit. A written consent was obtained from them to participate in the study. These 90 volunteers were then subjected to some simple experiments in the human physiology laboratory of the department of Kriya Sharir as described in the following paragraphs.

3.4. Recording the Cardiovascular Responses. The volunteers were subjected to different tests in multiple sessions so that only one test was performed during one session. Each session was separated by a gap of at least 24 hours. The time of performing these tests was from four p.m. to five p.m. in the human physiology laboratory of the department of Kriya Sharir. All these tests were performed in the months of comfortable environmental temperature, that is, August, September, October, and November, thus, avoiding the extreme winters and summers.

3.4.1. Recording the Basal Readings. Volunteers were asked to lie down in supine position for ten minutes and relax. After that, the arterial pulse rate per minute (PR), systolic blood pressure in $\mathrm{mm} \mathrm{Hg}$ (SBP) and diastolic blood pressure in $\mathrm{mm} \mathrm{Hg}$ (DBP) were recorded. 


\subsubsection{Recording the Effect of Posture}

(a) After recording the basal readings, the volunteers were asked to sit up quickly, and the PR, SBP, and the DBP were recorded immediately. After two minutes of assuming the sitting posture, the $\mathrm{PR}, \mathrm{SBP}$, and DBP were recorded once again.

(b) After this, the volunteers were asked to stand upright from the sitting posture as quickly as possible, and immediately, the PR, SBP, and DBP were recorded. The procedure of recording these parameters was repeated after two minutes of assuming the standing posture.

(c) After lying down in supine position for five minutes, the volunteers were asked to stand up quickly and the PR, SBP, and DBP were recorded as soon as possible. Procedure of recording these parameters was repeated after two minutes of standing upright.

\subsubsection{Recording the Effect of Isometric Exercise}

(a) After five minutes of rest, the PR, SBP, and DBP of the volunteers were recorded in the standing upright position.

(b) The volunteers were asked to push the wall with both their hands as forcefully as possible for three minutes, that is, to perform isometric exercise.

(c) Immediately after the completion of exercise for three minutes, PR, SBP, and DBP of the volunteers were recorded.

(d) Procedure of recording the PR, SBP, and DBP was repeated after two and five minutes of completion of the isometric exercise.

\subsubsection{Recording the Effect of Isotonic Exercise}

Harvard Step Test. In this test, the volunteers were asked to step up and down a 20-inch bench, at a frequency of 30 times/minute for five minutes [23]. If the subject felt breathlessness and exhausted, the test was stopped. Immediately after completion of five minutes of Harvard Step Test, the PR, SBP, and DBP were recorded. The procedure of recording the PR, SBP, and DBP was repeated after two and five minutes of completion of Harvard Step Test.

3.4.5. Recording the Cardiac Efficiency Index (CEI). To calculate the cardiac efficiency index, PR was recorded at the following three instances after the completion of Harvard Step Test, and the readings were designated as (a), (b), and (c):

(a) PR in between 1 and 1.5 minutes,

(b) PR in between 2 and 2.5 minutes,

(c) PR in between 3 and 3.5 minutes.
The cardiac efficiency index was calculated with the help of the following formula [23]:

$$
\frac{\text { Duration of Isotonic Exercise (in seconds) } \times 100}{a+b+c}=\ldots \% \text {. }
$$

3.4.6. Recording the Cold Pressor Test. In this test, right hand of the volunteer was immersed in cold water $\left(4^{\circ} \mathrm{C}\right)$ kept in a tumbler till the level of wrist, and PR, SBP, and DBP were recorded in the left hand every 30 seconds for 2 minutes [24].

3.5. Calculations and Statistical Analysis. The data entry was carried out using the software Statistical Package for Social Sciences (SPSS version 11.5). The means were calculated for all the recorded parameters with respect to each Prakriti group. For the purpose of intergroup comparison, One-way ANOVA was used.

\section{Observations}

Out of the 90 volunteers in the study, 61 were males and 29 were females. The maximum number of volunteers belonged to the age group of $18-26$ years $(n=72)$. When distributed in terms of constitutional types, the maximum number of volunteers were found to be belonging to Pitta-Kapha Prakriti $(n=50)$, and remaining volunteers were found to be distributed almost equally among Vata-Kapha $(n=21)$ and Vata-Pitta $(n=19)$ Prakriti groups.

It was interesting to note that, out of 150 volunteers who were screened initially, there was no individual who scored a zero for any Dosha. There was no individual who scored equal scores for all the three categories of Doshas either. The minimum percentage scores scored for a Dosha were $5 \%$ for Vata, 5\% for Pitta and 20\% for Kapha. In the same manner, the maximum percentage scores scored for a Dosha were 59\% for Vata, 89\% for Pitta and 81\% for Kapha. This means that the role of Vata, as a factor determining one's constitution, was minimal in this sample.

Tables 2, 3, 4, 5, and 6 reveal that no parameter showed any significant variation in accordance with the Prakriti groups. However, as Table 7 suggests, the DBP recorded immediately after performing the isotonic exercise for five minutes showed a definite variation $(P=.004)$ according to the constitutional type. The significant pairs were VP (mean DBP 97.79 \pm 5.159 ) versus VK (mean DBP 92.00 \pm 7.211 ) and PK (mean DBP 97.12 \pm 6.183 ) versus VK (mean DBP $92.00 \pm 7.211)$. This means that the fall in DBP was significant in VK group in comparison to VP and PK groups.

\section{Discussion}

The entire description of human Physiology in Ayurveda is based primarily on the theory of Tridosha. The "homeostatic mechanisms" as conceptualised in modern biomedicine have a very close resemblance with this theory. On the basis of this understanding, the three Doshas_Vata, Pitta and Kapha-can be paralleled with the nervous, endocrine, and immune mechanisms, respectively [4]. This is because, Vata 
TABLE 2: The relationship between Prakriti and the basal readings of PR (per minute), SBP ( $\mathrm{mm} \mathrm{Hg}$ ) and DBP (mm Hg).

\begin{tabular}{lccc}
\hline Prakriti & PR $($ Mean \pm SD $)$ & SBP $($ Mean \pm SD $)$ & DBP $($ Mean \pm SD $)$ \\
\hline VP $(n=19)$ & $79.42 \pm 7.883$ & $120.42 \pm 9.535$ & $75.47 \pm 6.859$ \\
PK $(n=50)$ & $79.74 \pm 8.444$ & $116.52 \pm 9.397$ & $76.32 \pm 7.153$ \\
VK $(n=21)$ & $78.76 \pm 4.538$ & $117.43 \pm 9.384$ & $72.67 \pm 7.193$ \\
Intergroup comparison Oneway ANOVA & $P=.885$ & $P=.311$ & $P=.146$ \\
\hline
\end{tabular}

TABLE 3: The effect of postural changes on PR (per minute), SBP (mm Hg), and DBP (mm Hg) in relation to Prakriti.

\begin{tabular}{|c|c|c|c|c|c|c|}
\hline Posture change & Parameter & Time of recording & $\mathrm{VP}(n=19)$ & $\mathrm{PK}(n=50)$ & $\mathrm{VK}(n=21)$ & $\begin{array}{c}\text { Intergroup comparison } \\
\text { One-way ANOVA }\end{array}$ \\
\hline \multirow{6}{*}{$\begin{array}{l}\text { Sitting from } \\
\text { supine }\end{array}$} & \multirow{2}{*}{$\mathrm{PR}($ Mean $\pm \mathrm{SD})$} & Immediate & $77.68 \pm 7.580$ & $79.08 \pm 7.690$ & $78.57 \pm 5.662$ & $P=.774$ \\
\hline & & After 2 minutes & $81.95 \pm 7.059$ & $82.36 \pm 8.218$ & $82.57 \pm 5.105$ & $P=.963$ \\
\hline & \multirow{2}{*}{ SBP $($ Mean \pm SD $)$} & Immediate & $115.58 \pm 9.651$ & $111.12 \pm 9.277$ & $113.43 \pm 9.320$ & $P=.195$ \\
\hline & & After 2 minutes & $122.32 \pm 9.220$ & $118.84 \pm 9.373$ & $121.14 \pm 9.264$ & $P=.329$ \\
\hline & \multirow{2}{*}{$\mathrm{DBP}($ Mean $\pm \mathrm{SD})$} & Immediate & $72.74 \pm 6.674$ & $73.24 \pm 6.950$ & $71.33 \pm 6.950$ & $P=.566$ \\
\hline & & After 2 minutes & $76.32 \pm 7.521$ & $76.88 \pm 6.517$ & $75.81 \pm 6.258$ & $P=.819$ \\
\hline \multirow{6}{*}{$\begin{array}{l}\text { Standing from } \\
\text { sitting }\end{array}$} & \multirow{2}{*}{$\mathrm{PR}($ Mean $\pm \mathrm{SD})$} & Immediate & $79.63 \pm 7.159$ & $79.98 \pm 4.883$ & $79.24 \pm 4.300$ & $P=.919$ \\
\hline & & After 2 minutes & $82.00 \pm 7.483$ & $82.94 \pm 8.102$ & $82.86 \pm 4.881$ & $P=.890$ \\
\hline & \multirow{2}{*}{ SBP $($ Mean \pm SD $)$} & Immediate & $117.58 \pm 10.167$ & $113.48 \pm 8.541$ & $116.10 \pm 10.010$ & $P=.216$ \\
\hline & & After 2 minutes & $123.05 \pm 9.222$ & $118.84 \pm 8.563$ & $121.62 \pm 9.135$ & $P=.166$ \\
\hline & \multirow{2}{*}{ DBP $($ Mean \pm SD $)$} & Immediate & $73.68 \pm 6.156$ & $74.64 \pm 6.471$ & $73.14 \pm 6.343$ & $P=.635$ \\
\hline & & After 2 minutes & $76.21 \pm 5.922$ & $76.88 \pm 6.223$ & $75.33 \pm 5.416$ & $P=.606$ \\
\hline \multirow{6}{*}{$\begin{array}{l}\text { Standing from } \\
\text { supine }\end{array}$} & \multirow{2}{*}{$\mathrm{PR}($ Mean $\pm \mathrm{SD})$} & Immediate & $78.32 \pm 7.952$ & $79.04 \pm 7.848$ & $79.81 \pm 4.729$ & $P=.810$ \\
\hline & & After 2 minutes & $83.26 \pm 7.279$ & $83.03 \pm 7.709$ & $83.33 \pm 4.520$ & $P=.984$ \\
\hline & \multirow{2}{*}{$\mathrm{SBP}($ Mean $\pm \mathrm{SD})$} & Immediate & $115.58 \pm 9.057$ & $111.60 \pm 8.843$ & $116.29 \pm 10.359$ & $P=.089$ \\
\hline & & After 2 minutes & $124.42 \pm 9.179$ & $119.64 \pm 8.473$ & $123.52 \pm 9.735$ & $P=.077$ \\
\hline & \multirow{2}{*}{$\mathrm{DBP}($ Mean $\pm \mathrm{SD})$} & Immediate & $72.53 \pm 5.806$ & $73.00 \pm 6.315$ & $72.48 \pm 5.437$ & $P=.926$ \\
\hline & & After 2 minutes & $76.84 \pm 5.937$ & $76.68 \pm 5.906$ & $76.67 \pm 4.830$ & $P=.994$ \\
\hline
\end{tabular}

TABLE 4: The relationship between Prakriti and PR (per minute), SBP ( $\mathrm{mm} \mathrm{Hg}$ ), and DBP ( $\mathrm{mm} \mathrm{Hg}$ ) recorded at different time intervals after performing the isometric exercise for 3 minutes.

\begin{tabular}{|c|c|c|c|c|c|}
\hline & & $\mathrm{VP}(n=19)$ & $\mathrm{PK}(n=50)$ & $\mathrm{VK}(n=21)$ & $\begin{array}{c}\text { Intergroup comparison } \\
\text { One-way ANOVA }\end{array}$ \\
\hline \multirow{3}{*}{$\begin{array}{l}\mathrm{PR} \\
(\text { Mean } \pm \mathrm{SD})\end{array}$} & Immediate & $88.74 \pm 8.143$ & $90.34 \pm 8.070$ & $89.14 \pm 5.534$ & $P=.680$ \\
\hline & After 2 minutes & $83.79 \pm 8.080$ & $84.80 \pm 7.762$ & $84.67 \pm 5.598$ & $P=.877$ \\
\hline & After 5 minutes & $80.53 \pm 8.051$ & $80.94 \pm 7.133$ & $81.52 \pm 4.729$ & $P=.898$ \\
\hline \multirow{3}{*}{$\begin{array}{l}\text { SBP } \\
(\text { Mean } \pm \text { SD })\end{array}$} & Immediate & $131.47 \pm 10.538$ & $128.28 \pm 10.222$ & $130.38 \pm 7.965$ & $P=.430$ \\
\hline & After 2 minutes & $124.53 \pm 9.137$ & $121.44 \pm 9.442$ & $124.57 \pm 8.322$ & $P=.281$ \\
\hline & After 5 minutes & $120.63 \pm 8.617$ & $118.02 \pm 8.904$ & $122.10 \pm 8.233$ & $P=.168$ \\
\hline \multirow{3}{*}{$\begin{array}{l}\text { DBP } \\
(\text { Mean } \pm \text { SD })\end{array}$} & Immediate & $90.00 \pm 6.254$ & $88.80 \pm 7.825$ & $88.10 \pm 6.340$ & $P=.700$ \\
\hline & After 2 minutes & $82.74 \pm 6.118$ & $81.48 \pm 7.192$ & $80.86 \pm 7.227$ & $P=.687$ \\
\hline & After 5 minutes & $80.00 \pm 5.249$ & $77.56 \pm 8.450$ & $77.71 \pm 6.581$ & $P=.465$ \\
\hline
\end{tabular}


TABLE 5: The relationship between Prakriti groups and cardiac efficiency index (CEI).

\begin{tabular}{|c|c|c|c|c|}
\hline \multirow[t]{2}{*}{ Prakriti } & \multicolumn{3}{|c|}{$\begin{array}{l}\text { PR (per minute) recorded at different time intervals after } \\
\text { completing the Harvard step test for } 5 \text { minutes }\end{array}$} & \multirow{2}{*}{$\begin{array}{l}\text { CEI (in \%) } \\
\text { Cardiac efficiency index } \\
\quad(\text { Mean } \pm \text { SD) }\end{array}$} \\
\hline & $\begin{array}{l}\text { PR between } 1-1.5 \text { minutes } \\
(\text { Mean } \pm \mathrm{SD})\end{array}$ & $\begin{array}{l}\text { PR between } 2-2.5 \text { minutes } \\
(\text { Mean } \pm \text { SD })\end{array}$ & $\begin{array}{l}\text { PR between } 3-3.5 \text { minutes } \\
(\text { Mean } \pm \text { SD })\end{array}$ & \\
\hline $\operatorname{VP}(n=19)$ & $98.00 \pm 6.110$ & $92.42 \pm 6.203$ & $88.47 \pm 6.168$ & $107.77 \pm 7.425$ \\
\hline $\mathrm{PK}(n=50)$ & $100.06 \pm 8.052$ & $93.36 \pm 7.105$ & $87.36 \pm 3.766$ & $106.50 \pm 8.443$ \\
\hline $\mathrm{VK}(n=21)$ & $98.81 \pm 6.493$ & $93.14 \pm 5.121$ & $89.05 \pm 4.318$ & $106.84 \pm 5.672$ \\
\hline $\begin{array}{l}\text { Intergroup comparison } \\
\text { One-way ANOVA }\end{array}$ & $P=.545$ & $P=.867$ & $P=.818$ & $P=.830$ \\
\hline
\end{tabular}

TABle 6: The relationship between Prakriti and PR (per minute), SBP (mm Hg), and DBP (mm Hg) recorded at different time intervals during the cold pressor test.

\begin{tabular}{|c|c|c|c|c|c|}
\hline Parameter & Time of recording & $\mathrm{VP}(n=19)$ & $\mathrm{PK}(n=50)$ & $\mathrm{VK}(n=21)$ & $\begin{array}{c}\text { Intergroup comparison } \\
\text { One-way ANOVA }\end{array}$ \\
\hline \multirow{4}{*}{$\begin{array}{l}\mathrm{PR} \\
(\text { Mean } \pm \mathrm{SD})\end{array}$} & After 30 seconds & $82.21 \pm 7.598$ & $83.20 \pm 7.751$ & $83.24 \pm 4.358$ & $P=.861$ \\
\hline & After 60 seconds & $89.16 \pm 7.669$ & $89.96 \pm 7.956$ & $89.62 \pm 4.318$ & $P=.917$ \\
\hline & After 90 seconds & $94.68 \pm 6.717$ & $95.48 \pm 7.841$ & $94.29 \pm 4.660$ & $P=.783$ \\
\hline & After 120 seconds & $95.53 \pm 6.915$ & $95.40 \pm 7.892$ & $94.10 \pm 4.625$ & $P=.748$ \\
\hline \multirow{4}{*}{$\begin{array}{l}\text { SBP } \\
(\text { Mean } \pm \text { SD })\end{array}$} & After 30 seconds & $125.47 \pm 8.161$ & $121.24 \pm 8.989$ & $123.71 \pm 8.131$ & $P=.165$ \\
\hline & After 60 seconds & $132.11 \pm 9.273$ & $128.68 \pm 9.576$ & $130.48 \pm 8.195$ & $P=.365$ \\
\hline & After 90 seconds & $138.11 \pm 8.232$ & $134.16 \pm 9.213$ & $134.86 \pm 7.472$ & $P=.240$ \\
\hline & After 120 seconds & $138.42 \pm 8.044$ & $134.12 \pm 9.358$ & $135.71 \pm 7.135$ & $P=.183$ \\
\hline \multirow{4}{*}{$\begin{array}{l}\text { DBP } \\
(\text { Mean } \pm \text { SD })\end{array}$} & After 30 seconds & $79.26 \pm 7.187$ & $78.84 \pm 6.810$ & $76.10 \pm 6.276$ & $P=.237$ \\
\hline & After 60 seconds & $83.05 \pm 6.745$ & $83.00 \pm 6.812$ & $80.19 \pm 6.129$ & $P=.239$ \\
\hline & After 90 seconds & $85.89 \pm 6.879$ & $84.88 \pm 6.942$ & $82.86 \pm 6.650$ & $P=.352$ \\
\hline & After 120 seconds & $86.95 \pm 6.811$ & $85.28 \pm 6.758$ & $82.67 \pm 6.272$ & $P=.123$ \\
\hline
\end{tabular}

TABLE 7: The relationship between Prakriti and PR (per minute), SBP ( $\mathrm{mm} \mathrm{Hg}$ ) and DBP (mm Hg) recorded at different time intervals after performing the isotonic exercise for 5 minutes.

\begin{tabular}{|c|c|c|c|c|c|c|}
\hline & & $\mathrm{VP}(n=19)$ & $\mathrm{PK}(n=50)$ & $\mathrm{VK}(n=21)$ & \multicolumn{2}{|c|}{ Intergroup comparison } \\
\hline & & & & & One-way ANOVA & $\begin{array}{c}\text { Post hoc test }(\mathrm{LSD}) \\
\text { significant pairs }(P<.05)\end{array}$ \\
\hline \multirow{3}{*}{$\begin{array}{l}\mathrm{PR} \\
(\text { Mean } \pm \mathrm{SD})\end{array}$} & Immediate & $103.16 \pm 5.824$ & $104.84 \pm 9.303$ & $104.29 \pm 8.632$ & $P=.765$ & - \\
\hline & After 2 minutes & $92.79 \pm 6.469$ & $93.94 \pm 7.490$ & $94.19 \pm 5.862$ & $P=.785$ & - \\
\hline & After 5 minutes & $82.95 \pm 5.512$ & $84.12 \pm 6.483$ & $84.86 \pm 4.408$ & $P=.586$ & - \\
\hline \multirow{3}{*}{$\begin{array}{l}\text { SBP } \\
(\text { Mean } \pm \text { SD })\end{array}$} & Immediate & $148.84 \pm 6.677$ & $147.24 \pm 8.627$ & $143.05 \pm 7.473$ & $P=.056$ & - \\
\hline & After 2 minutes & $136.21 \pm 6.494$ & $134.92 \pm 8.864$ & $132.29 \pm 7.932$ & $P=.295$ & - \\
\hline & After 5 minutes & $125.26 \pm 6.402$ & $123.84 \pm 8.210$ & $123.43 \pm 6.266$ & $P=.709$ & - \\
\hline \multirow{3}{*}{$\begin{array}{l}\text { DBP } \\
(\text { Mean } \pm \text { SD })\end{array}$} & Immediate & $97.79 \pm 5.159$ & $97.12 \pm 6.183$ & $92.00 \pm 7.211$ & $P=.004$ & $\begin{array}{l}\text { VP versus } \mathrm{VK} \text { and } \mathrm{PK} \\
\text { versus } \mathrm{VK}\end{array}$ \\
\hline & After 2 minutes & $88.63 \pm 4.810$ & $88.80 \pm 5.628$ & $85.43 \pm 6.547$ & $P=.070$ & - \\
\hline & After 5 minutes & $81.68 \pm 4.773$ & $80.84 \pm 5.270$ & $78.38 \pm 6.249$ & $P=.122$ & - \\
\hline
\end{tabular}




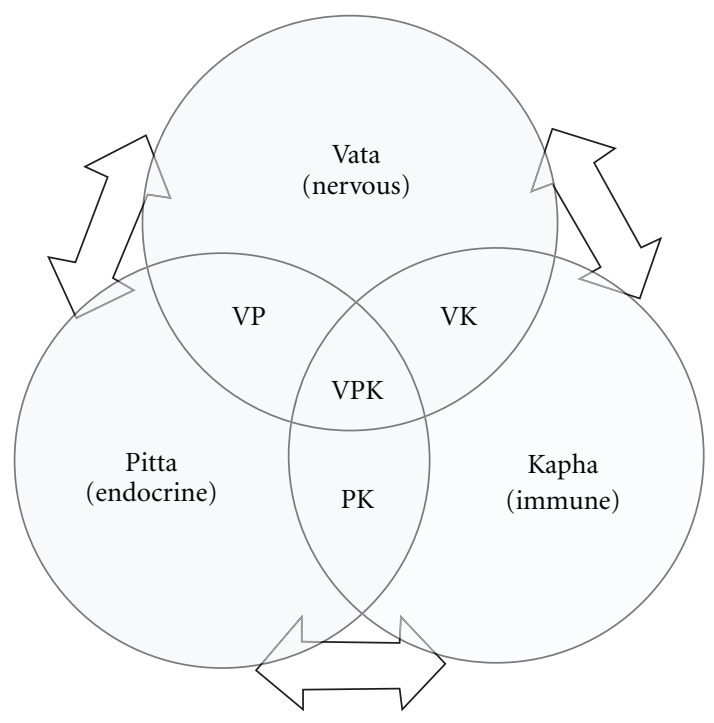

Figure 1

primarily initiates all the sensory and motor activities, Pitta controls digestion and metabolism, and Kappha confers immunity [4]. In fact, the modern biomedicine has only recently started taking note of the important interactions that take place between nervous, endocrine, and immune mechanisms and their role in the maintenance of homeostasis. For instance, the central nervous system influences the immune system through endocrine, paracrine and neuronal mechanisms. Immune cells produce a large number of endocrine hormones, neurotransmitters, and neuropeptides and are involved in the regulation of immunity. The endocrine and nervous systems express receptors for a wide variety of immunologically derived substances, suggesting potential regulatory feedback loops between these three major integrative bodily systems $[4,25]$. Therefore, it can be presumed that the nervous, endocrine, and immune systems dominate the overall homeostatic regulatory scenario among the people with Vata, Pitta and Kapha types of constitutions respectively. Figure 1 represents this hypothesis schematically. This understanding may support the view expressed by Hankey A that the CAM modalities can stimulate advances in theoretical biology [26].

Recently, there have been several efforts to provide an evidence base to the traditional systems of medicine [2730 ], and a number of investigators have tried to provide some interesting genetic, biochemical, haematological or anatomical basis to the concept of Ayurveda constitution. But, most of the recent investigations carried out in relation to Prakriti have included only those individuals belonging to three extreme types of constitutions, which is comparatively a rare occurrence in our experience. Apart from this, the accurate assessment of one's constitution has always been a problem.

The present study tries to overcome most of the problems encountered while assessing one's Prakriti because the questionnaire used in this study is of "self-assessment" type and is based only on one classical textbook, that is, Charaka
Samhita, and thus avoids the inclusion of contradictory views. Furthermore, the mathematical model incorporated in this questionnaire is based on the sound logic of "Guna" principle of Ayurveda. In this study, we included only those individuals with a dual type of constitution (produced due to the physiological dominance of two Doshas) and investigated for any possible correlation between the responses of certain basic cardiovascular parameters and the constitutional types.

Most of these basic cardiovascular responses that we studied have been proposed to have some predictive clinical significance. While Matthews and others suggest that the people who are at high risk for elevated blood pressure might have an exaggerated stress-induced cardiovascular response at a younger age [31], Sparrow and others advocate a possible relationship between the postural changes in diastolic blood pressure and the risk of subsequent myocardial infarction [32]. Ellestad and Wan, in 1975, showed that the lack of an appropriate heart rate response to exercise, termed "Chronotropic incompetence," was associated with a greater risk of adverse cardiac events in the next five years than was ST segment depression [33]. Similarly, an exaggerated blood pressure response during exercise is probably an independent predictor of future hypertension [34, 35]. The clinical importance of the cold pressor test has been highlighted by Kasagi $F$ and others. Their study supports the hypothesis that hyper reactivity to the cold pressor test is a predictor of the development of hypertension [36].

Though, the present study does not suggest any significant association between the Prakriti type and cardiovascular responses in the form of $\mathrm{HR}, \mathrm{SBP}$, and $\mathrm{DBP}$ to the changes in posture, isometric exercise, and cold pressor test, it suggests a possibility that the individuals with a dual type of constitution may differ significantly from those with an extreme type. It is being hypothesised that, the association of a secondary Dosha that has a nullifying/opposite effect due to the reciprocal relationship that it shares with the primary Dosha, may be responsible for this phenomenon. Therefore, it is being suggested that the prediction of any future morbidity based simply on Prakriti is difficult among the people belonging to the dual constitutional types. The study also suggests that the chances of encountering an individual with a truly extreme type of constitution are rare, and each Dosha probably contributes its share in framing ones' constitution, though at varying degrees.

A significant fall in DBP among Vata-Kapha individuals, recorded immediately after performing the isotonic exercise for five minutes, in comparison to Pitta-Kapha and VataPitta individuals is another observation that is noteworthy. In fact, the isotonic exercise produces varying degrees of vasodilatation in different individuals. This is possibly related to the proportion of adrenaline and noradrenaline released into the blood stream during vigorous exercise. The affinities of these chemicals towards alpha and beta adrenergic receptors differ, and this may form the basis of the differences noted in the DBP response between different individuals [37]. As the study suggests, vasodilatation and resultant fall in peripheral resistance predominates among Vata-Kapha individuals after the isotonic exercise in comparison to the other two groups. This supports the Ayurveda theory that Pitta is related with 
aggressiveness because of its Tikshna (sharp) Guna [5]. An individual with Pitta dominant Prakriti is usually involved in risky/heroic acts and gets angry/irritated easily [5]. This observation may support the findings related to higher levels of catecholamines in Pitta individuals as suggested by Udupa $\mathrm{KN}$ and others [14]. As the role of Pitta in VK group is minimal in comparison to VP or PK groups, it may be presumed that the dominance of Pitta has got some positive relationship with adrenal medullary hormones, sympathetic activity and/or with such other mechanisms that regulate the total peripheral resistance. This factor may be taken as a lead and further studies may be designed to explore this relationship.

\section{Summary and Conclusion}

It may be concluded that the modified self-assessment questionnaire that we have used in the present study measures the dominance of Dosha to a fairly reliable extent and may be used to quantitatively express the Dosha dominance. Though, the study indicates that the basic cardiovascular responses do not significantly vary in accordance with the dual constitutional types of Ayurveda, it suggests that the fall in DBP recorded immediately after performing the isotonic exercise for five minutes varies significantly in relation to Prakriti groups and this fall is significant among VK group in comparison to VP and PK groups. This finding is indicative of some kind of positive association of Pitta with adrenal medullary hormones, sympathetic activity and/or such other mechanisms that regulate the total peripheral resistance. The study may also be considered as a lead to further investigations as to whether the individuals with a dual constitutional type differ significantly from those with an extreme constitutional type or not. A similar study, if carried out among the individuals belonging to truly extreme constitutional types, may throw some more light in this regard.

\section{Acknowledgment}

The authors acknowledge the support and facilities they received from the Department of Kriya Sharir, Faculty of Ayurveda, Banaras Hindu University, during the present work.

\section{References}

[1] K. R. S. Murthy, Sushruta Samhita, Sharira Sthana, Jaikrishnadas Ayurveda Series No.102, chapter 4, Chaukhambha Orientalia, Varanasi, India, 2008.

[2] S. Rastogi, "Building bridges between Ayurveda and Modern Science," International Journal of Ayurveda Research, vol. 1, no. 1, pp. 41-46, 2010.

[3] B. Prasher, S. Negi, S. Aggarwal, A. K. Mandal, T. P. Sethi, and S. R. Deshmukh, "Whole genome expression and biochemical correlates of extreme constitutional types defined in Ayurveda," Journal of Translational Medicine, vol. 6, article no. $48,2008$.
[4] K. Patwardhan, Human Physiology in Ayurveda, Jiakrishnadas Series No.134, Chaukhambha Orientalia, Varanasi, India, 2008.

[5] P. V. Sharma, Charaka Samhita, Vimana Sthana, vol. 1 of Jaikrishnadas Ayurveda Series No.36, chapter 8, Chaukhambha Orientalia, Varanasi, India, 2008.

[6] G.-L. Kang, S. Li, and J.-F. Zhang, "Entropy-based model for interpreting life systems in traditional Chinese medicine," Evidence-Based Complementary and Alternative Medicine, vol. 5, no. 3, pp. 273-279, 2008.

[7] S. Kanba, K. Yamada, H. Mizushima, and M. Asai, "Use of herbal medicine for treating psychiatric disorders in Japan," Psychiatry and Clinical Neurosciences, vol. 52, supplement, pp. S331-S333, 1998.

[8] B. Patwardhan, D. Warude, P. Pushpangadan, and N. Bhatt, "Ayurveda and traditional Chinese medicine: a comparative overview," Evidence-Based Complementary and Alternative Medicine, vol. 2, no. 4, pp. 465-473, 2005.

[9] J. Y. Kim, D. D. Pham, and B. H. Koh, "Comparison of Sasang constitutional medicine, traditional chinese medicine and Ayurveda," Evidence-Based Complementary and Alternative Medicine. In press.

[10] E. Kretschmer and W. J. H. Sprott, "Physique and character," in An Investigation of the Nature of Constitution and the Theory of Temperament, Harcourt Brace, NY, USA, 1925.

[11] J. E. Phares, Introduction to Personality, Harper Collins, NY, USA, 3rd edition, 1991.

[12] H. J. Eysenck and M. W. Eysenck, Personality and Individual Differences, Plenum Press, NY, USA, 1985.

[13] S. H. Park, M. Kim, S. J. Lee, J. Y. Kim, and H. Chae, "Temperament and character profiles of Sasang typology in an adult clinical sample," Evidence-Based Complementary and Alternative Medicine. In press.

[14] K. N. Udupa, R. H. Singh, G. P. Dubey, V. Rai, and M. B. Singh, "Biochemical basis of psychosomatic constitution (Prakriti)," Indian Journal of Medical Research, vol. 63, no. 7, pp. 923-927, 1975.

[15] B. Patwardhan and G. Bodeker, "Ayurvedic genomics: establishing a genetic basis for mind-body typologies," Journal of Alternative and Complementary Medicine, vol. 14, no. 5, pp. 571-576, 2008.

[16] B. Patwardhan, K. Joshi, and A. Chopra, "Classification of human population based on HLA gene polymorphism and the concept of Prakriti in Ayurveda," Journal of Alternative and Complementary Medicine, vol. 11, no. 2, pp. 349-353, 2005.

[17] Y. Ghodke, K. Joshi, and B. Patwardhan, "Traditional medicine to modern pharmacogenomics: Ayurveda Prakriti type and CYP2C19 gene polymorphism associated with the metabolic variability," Evidence-Based Complementary and Alternative Medicine. In press.

[18] S.-W. Lee, E.-S. Jang, J. Lee, and J. Y. Kim, "Current researches on the methods of diagnosing sasang constitution: an overview," Evidence-Based Complementary and Alternative Medicine, vol. 6, no. 1, pp. 43-49, 2009.

[19] K. Patwardhan and R. Sharma, "Prakriti: a self-assessment questionnaire," Journal of All India Sharir Research Institute, vol. 1, no. 5, pp. 11-16, 2005.

[20] K. Patwardhan, S. Gehlot, G. Singh, and H. C. S. Rathore, "The Ayurveda education in India: how well are the graduates exposed to basic clinical skills?" Evidence-Based Complementary and Alternative Medicine. In press. 
[21] J. Cohen, Statistical Power Analysis for the Behavioural Sciences, Erlbaum, Hillsdale, NJ, USA, 2nd edition, 1988.

[22] G. Singh, "A shift from significance test to hypothesis test through power analysis in medical research," Journal of Postgraduate Medicine, vol. 52, no. 2, pp. 148-150, 2006.

[23] L. Brouha, C. W. Health, and A. Graybiel, "Step test simple method of measuring physical fitness for hard muscular work in adult men," Reviews of Canadian Biology, vol. 2, p. 86, 1943.

[24] F. Weise, D. Laude, A. Girard, P. Zitoun, J.-P. Siche, and J.L. Eeghozi, "Effects of the cold pressor test on short-term fluctuations of finger arterial blood pressure and heart rate in normal subjects," Clinical Autonomic Research, vol. 3, no. 5, pp. 303-310, 1993.

[25] B. Marchetti, M. C. Morale, F. Gallo, N. Batticane, Z. Farinella, and M. Cioni, "Neuroendocrineimmunology (NEI) at the turn of the century: towards a molecular understanding of basic mechanisms and implications for reproductive physiopathology," Endocrine, vol. 3, no. 12, pp. 845-861, 1995.

[26] A. Hankey, "CAM modalities can stimulate advances in theoretical biology," Evidence-Based Complementary and Alternative Medicine, vol. 2, no. 1, pp. 5-12, 2005.

[27] R. A. Mashelkar, "Second world Ayurveda Congress (Theme: Ayurveda for the future)-inaugural address: part II," Evidence-Based Complementary and Alternative Medicine, vol. 5, no. 3, pp. 243-245, 2008.

[28] J. Y. Kim and D. D. Pham, "Sasang constitutional medicine as a holistic tailored medicine," Evidence-Based Complementary and Alternative Medicine, vol. 6, no. 1, pp. 11-19, 2009.

[29] B.-Y. Kim, S. Cha, H.-J. Jin, and S. Jeong, "Genetic approach to elucidation of sasang constitutional medicine," Evidence-Based Complementary and Alternative Medicine, vol. 6, no. 1, pp. 5157, 2009.

[30] M. S. Valiathan and U. Thatte, "Ayurveda: the time to experiment," International Journal of Ayurveda Research, vol. 1 , no. 1, p. 3, 2010 .

[31] K. A. Matthews, K. L. Woodall, and M. T. Allen, "Cardiovascular reactivity to stress predicts future blood pressure status," Hypertension, vol. 22, no. 4, pp. 479-485, 1993.

[32] D. Sparrow, C. P. Tifft, B. Rosner, and S. T. Weiss, "Postural changes in diastolic blood pressure and the risk of myocardial infarction: the normative aging study," Circulation, vol. 70, no. 4, pp. 533-537, 1984.

[33] M. H. Ellestad and M. K. C. Wan, "Predictive implications of stress testing. Follow up of 2700 subjects after maximum treadmill stress testing," Circulation, vol. 51, no. 2, pp. 363 369, 1975.

[34] N. Miyai, M. Arita, K. Miyashita, I. Morioka, T. Shiraishi, and I. Nishio, "Blood pressure response to heart rate during exercise test and risk of future hypertension," Hypertension, vol. 39, no. 3, pp. 761-766, 2002.

[35] C. E. Matthews, R. R. Pate, K. L. Jackson et al., "Exaggerated blood pressure response to dynamic exercise and risk of future hypertension," Journal of Clinical Epidemiology, vol. 51, no. 1, pp. 29-35, 1998.

[36] F. Kasagi, M. Akahoshi, and K. Shimaoka, "Relation between cold pressor test and development of hypertension based on 28-year follow-up," Hypertension, vol. 25, no. 1, pp. 71-76, 1995.

[37] A. C. Guyton and J. E. Hall, "Muscle blood flow and cardiac output during exercise; the coronary circulation and ischemic heart disease," in Textbook of Medical Physiology, pp. 246-257, Elsevier, Philadelphia, Pa, USA, 11th edition, 2006. 


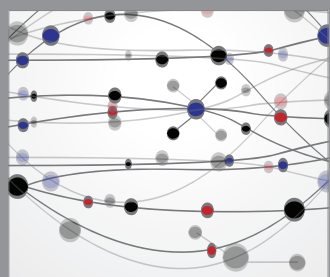

The Scientific World Journal
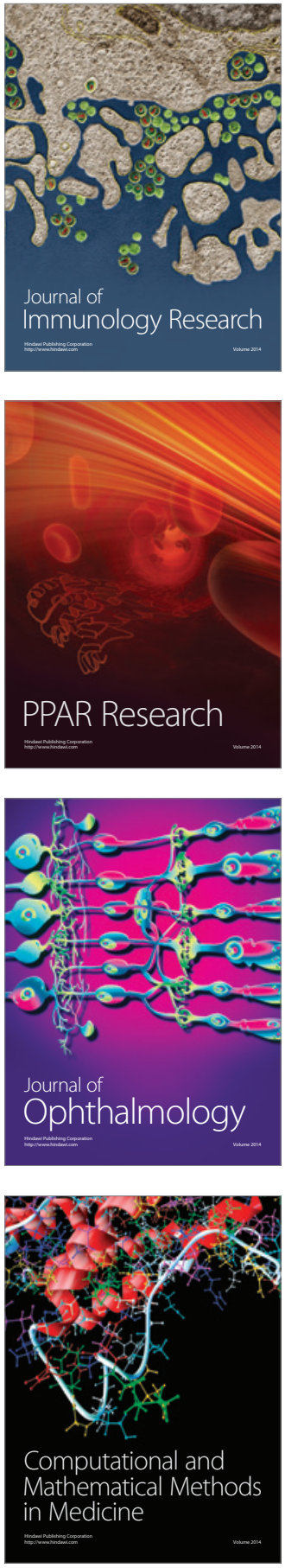

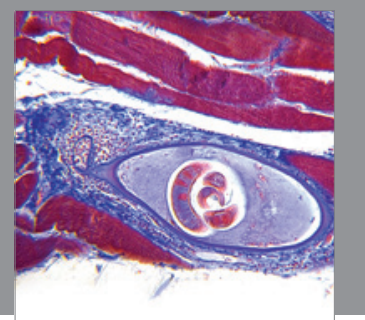

Gastroenterology

Research and Practice
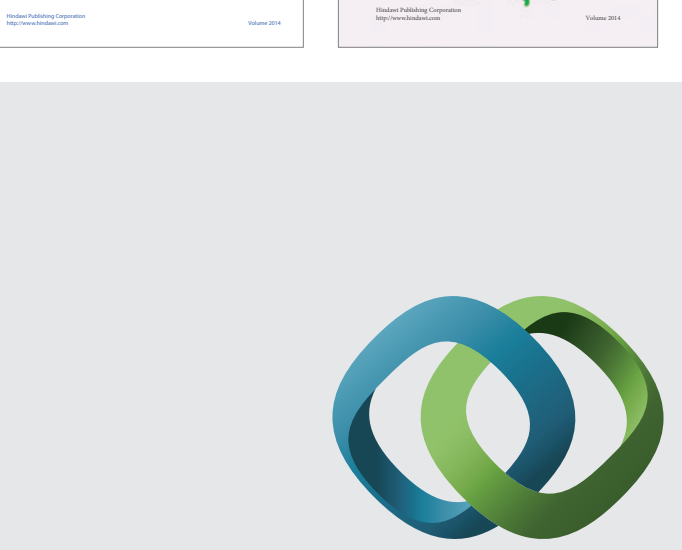

\section{Hindawi}

Submit your manuscripts at

http://www.hindawi.com
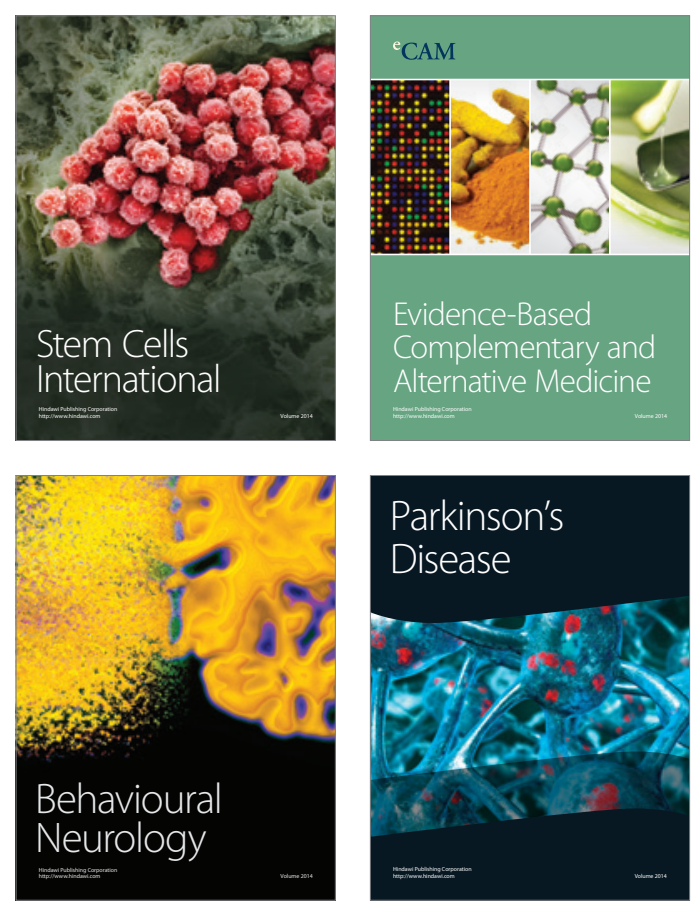

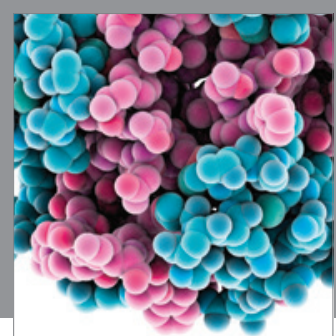

Journal of
Diabetes Research

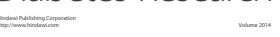

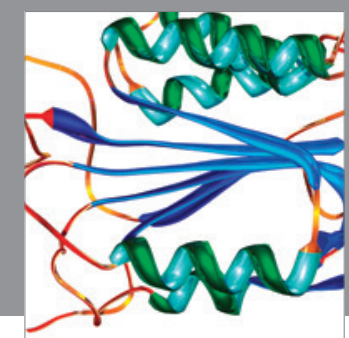

Disease Markers
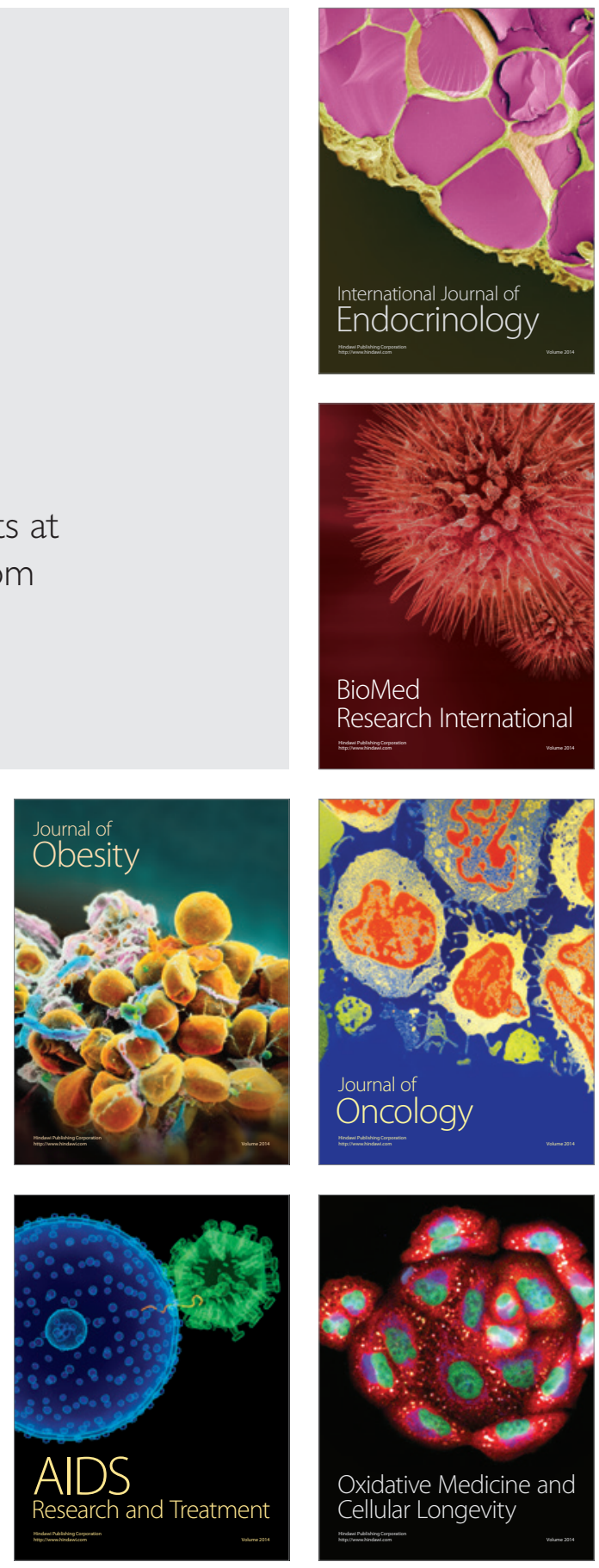